\title{
Dampak Obat-obat Terlarang dan Upaya Pengawasan Dini kepada Anak- anak Usia Sekolah Untuk Kelompok Ibu-ibu di Kelurahan Meras Kecamatan Bunaken Manado
}

\author{
Febby Ester Fany Kandou ${ }^{1 *}$, Edwin de Queljoe $^{2}$ \\ 1,2 Jurusan Biologi, Fakultas Matematika dan Ilmu Pengetahuan Alam, Universitas Sam Ratulangi Manado \\ 95115, Sulawesi Utara, Indonesia. \\ *Penulis korespondensi: Febby Kandou, Jurusan Biologi FMIPA Unsrat \\ Email: febbykandou@unsrat.ac.id
}

\begin{abstract}
ABSTRAK
Penggunaan obat-obat terlarang dan turunannya di kalangan anak-anak usia sekolah (pelajar) menjadi peringatan bagi para orangtua, jika lengah pengawasan maka anak-anak akan mudah terjerat dengan obat-obat terlarang. Berdasarkan data BNN Kota Manado selang 2015-2017 penyalahgunaan obat-obat terlarang dikalangan pelajar sebanyak 478 orang. Sepanjang tahun 2017 sekitar $85 \%$ pecandu yang direhabilitasi berasal dari kalangan pelajar. Kegiatan ini bertujuan untuk memberikan informasi atau pengetahuan kepada kelompok ibu-ibu tentang dampak obat-obat terlarang dan upaya pengawasan dini kepada anak-anak usia sekolah. Metode yang digunakan adalah dengan memberikan penyuluhan atau sosialisasi kepada para orangtua khususnya ibu-ibu tentang dampak penggunaan obat-obat terlarang dan upaya pengawasan dini kepada anak-anak usia sekolah (pelajar). Selain penyuluhan/sosialisasi, ditambahkan kegiatan simulasi untuk memotivasi para orangtua khususnya ibuibu untuk berperan aktif sebagai motivator dalam memerangi obat-obat terlarang yang dimulai dari lingkungan keluarga maupun masyarakat pada umumnya. Capain kegiatan ini adalah para orangtua khususnya ibu-ibu paham tentang bahaya obat-obat terlarang, mengedukasi anak-anak untuk menghindar dari obat terlarang, melakukan kegiatan-kegiatan positif bersama dengan anak-anak seperti kegiatan keagamaan, seni dan olahraga, menjadi motivator antinarkoba di lingkungan masyarakat dengan memberikan informasi-informasi tentang bahaya dan pencegahannya baik dilingkup keluarga masing-masing maupun di lingkungan tempat kerja.
\end{abstract}

Kata kunci: dampak, obat terlarang, anak usia sekolah, Meras

\section{PENDAHULUAN}

\section{Analisis Situasi}

Masyarakat Kelurahan Meras

Kecamatan Bunaken Manado merupakan kelompok masyarakat yang datang dari berbagai daerah. Kegiatan kemasyarakatan berjalan dengan baik, juga hubungan sosial dan ekonomi dalam masyarakat. Profesi dari anggota masyarakat Kelurahan Meras meliputi petani, nelayan dan pegawai negeri maupun swasta. Kecamatan Bunaken merupakan salah satu kecamatan dari sebelas kecamatan yang ada di Kota Manado dan terdiri dari lima kelurahan yaitu, Kelurahan Molas, Kelurahan Bailang,
Kelurahan Tongkeina, Kelurahan Pandu dan Kelurahan Meras. Luas Wilayah Kecamatan Bunaken (Wilayah Daratan) adalah 3.183,07 Ha. Kecamatan Bunaken berbatasan dengan:

- Sebelah Utara berbatasan dengan Kabupaten Minahasa Utara

- Sebelah Timur berbatasan dengan Kecamatan Mapanget

- Sebelah Selatan berbatasan dengan Kecamatan Tuminting

- Sebelah Barat berbatasan dengan Kecamatan Bunaken Kepulauan dan Teluk Manado (Makawekes et al. 2016).

Perkembangan pada sektor pariwisata di Sulawesi Utara sudah membaik, jalur-jalur 
VIVABIO

Jurnal Pengabdian Multidisiplin

transportasi baik udara, laut maupun darat semakin terbuka sehingga hal ini dapat menjadi salah satu gerbang pintu masuk perdagangan obat-obat terlarang. Meskipun telah ditegaskan dengan ancaman pidana baik untuk pengedar maupun pemakai, tetap saja perdagangan ini terus berjalan bahkan sampai menyusup di sekolahsekolah. Keberadaan UU No 35 tahun 2009 tentang Narkotika yang juga mengatur tentang ancaman pidana bagi pemakai maupun pengedar seakan tidak diperdulikan oleh para pengedar maupun pemakai.

Penyalahgunaan dan peredaran gelap obat-obat terlarang telah menyasar ke semua strata kehidupan masyarakat, tanpa mengenal status sosial masyarakat. Pada masa lalu, sebagian besar pengguna atau pecandu obat berasal dari keluarga berantakan, namun saat ini fenomena itu telah meluas hingga menjangkau keluarga-keluarga dengan kategori usia, jenis kelamin, pekerjaan, dari rakyat biasa hingga tokoh masyarakat. Oleh sebab itu diperlukan pemahaman dan pengetahuan sejak dini mengenai dampak obat-obat terlarang tersebut. Seiring dengan kemajuan informasi dan teknologi serta pergaulan anggota masyarakat yang semakin luas, maka hal ini dapat mempengaruhi kondisi sosial, budaya, religi, dan ekonomi masyarakat. Penggunaan obat-obat terlarang bukan hanya mencakup orang dewasa saja yang sudah memiliki karier dan penghasilan, akan tetapi data yang ada menunjukkan bahwa pengguna bahkan pengedar juga masih usia remaja atau pemuda, yang tergolong masih mengenyam bangku pendidikan. Data BNN Kota Manado selang 2015-2017 penyalahgunaan obatobat terlarang dikalangan pelajar sebanyak 478 orang. Sepanjang tahun 2017 sekitar 85\% pecandu yang direhabilitasi berasal dari kalangan pelajar.

Berdasarkan informasi yang diperoleh tim pengusul sebelum merencanakan program ini, yaitu kurangnya informasi menyangkut obatobat terlarang serta akibat yang ditimbulkannya. Lokasi mitra yang berada di bagian paling utara Kota Manado dimana akses informasinya cukup minim sehingga lebih mudah untuk bersentuhan dengan orang-orang yang terlibat dalam pengedaran obat-obat terlarang, apalagi lokasi ini merupakan salah satu tujuan wisata. Untuk itu dibutuhkan suatu penyuluhan atau sosialisasi tentang dampak obat-obat terlarang dan penyakitpenyakit yang ditimbulkannya akibat mengkonsumsi obat-obat terlarang, gejala-gejala psikis serta bagaimana upaya pencegahan serta pengawasan dini kepada anak-anak usia sekolah dengan melibatkan narasumber yang kompeten dibidangnya.

\section{Tujuan dan Manfaat Kegiatan}

Kegiatan ini bertujuan untuk memberikan informasi/pengetahuan tentang dampak obat-obat terlarang dan upaya pengawasan dini kepada anak-anak usia sekolah. Manfaat kegiatan adalah para orangtua khususnya ibu-ibu paham tentang bahaya obatobat terlarang, mengedukasi anak-anak untuk menghindar dari obat terlarang, melakukan kegiatan-kegiatan positif bersama dengan anakanak seperti kegiatan keagamaan, seni dan olahraga, menjadi motivator antinarkoba di lingkungan masyarakat dengan memberikan informasi-informasi tentang bahaya dan pencegahannya baik dilingkup keluarga masingmasing maupun di lingkungan tempat kerja. Luaran yang dihasilkan orangtua khususnya ibuibu mendapatkan pengetahuan tentang bahaya obat-obat terlarang serta dapat menjadi motivator bagi keluarga dan di lingkungan masyarakat.

\section{METODE PELAKSANAAN}

\section{Sasaran kegiatan pengabdian}

Sebagai mitra dalam kegiatan pengabdian ini adalah Kelompok Ibu-ibu. Dipilihnya mitra kaum ibu karena peranan dari kaum ibu dalam keluarga cukup besar, selain itu mempunyai banyak waktu untuk mengawasi keluarga dalam hal ini anak-anak.

\section{Lokasi kegiatan pengabdian}

Kelurahan Meras Kecamatan Bunaken

Manado

\section{Metode yang digunakan}


VIVABIO

Jurnal Pengabdian Multidisiplin

Adapun metode pelaksanaan dari kegiatan ini adalah sebagai berikut:

1. Memberikan penyuluhan kepada kelompok ibibu di Kelurahan Meras Kecamatan Bunaken, dengan materi penyuluhan meliputi:

- pengertian obat-obat terlarang,

- jenis-jenis obat mana saja yang tergolong obat terlarang,

- bagaimana dampak bagi kesehatan jika mengkonsumsi obat-obat terlarang,

- penyakit-penyakit apa saja yang ditimbulkan dan gejala-gejala psikis yang muncul,

- bagaimana upaya pencegahan dan pengawasan dini kepada anak-anak usia sekolah

2. Selain penyuluhan/sosialisasi, ditambahkan kegiatan simulasi untuk memotivasi warga masyarakat khususnya kaum ibu untuk berperan aktif sebagai motivator dalam memerangi narkotika dan obat-obat terlarang yang dimulai dari lingkungan keluarga maupun masyarakat pada umumnya

\section{HASIL DAN PEMBAHASAN}

Kegiatan pengabdian ini telah dilaksanakan pada hari Kamis, tanggal 9 Agustus 2018 pukul 10.00 wita di Kelurahan Meras Kecamatan Bunaken Manado. Penyuluhan/sosialisasi diikuti oleh 37 orang peserta mitra. Kegiatan dibagi menjadi dua bagian, yaitu sessi pertama sosialisasi dampak penggunaan obat-obat terlarang dan penyakitpenyakit yang ditimbulkannya, selanjutnya sessi kedua penyuluhan dan simulasi upaya pengawasan dini kepada anak-anak usia sekolah (pelajar) serta memotivasi warga masyarakat khususnya kaum ibu untuk berperan aktif sebagai motivator dalam memerangi obat-obat terlarang. Dalam kegiatan ini nampak para peserta begitu antusias untuk mengajukan pertanyaan seputar obat-obat terlarang, dan merasa puas setelah mendengar jawaban dari pemateri.
Pada kegiatan ini dijelaskan pengertian narkotika, psikotropika dan zat adiktif serta peraturan perundang-undangan yang mengatur tentang hal tersebut. Narkoba berdasarkan jenisnya serta bahaya yang ditimbulkan bagi kesehatan manusia, seperti merusak sistem pernafasan, sistem peredaran darah, gangguan sistem saraf pusat, perubahan fungsi otak, disfungsi hati, merusak sistem imun dalam tubuh, gangguan sistem reproduksi serta merusak mental.

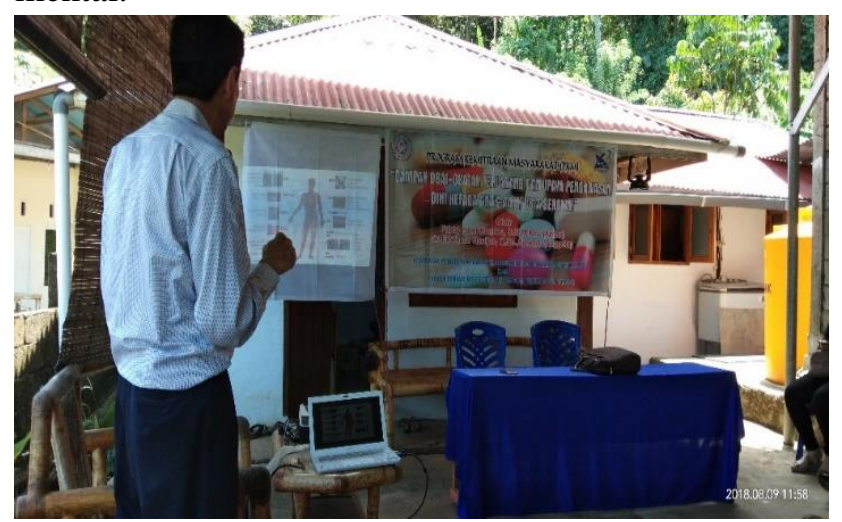

Gambar 1. Kegiatan sosialisasi dampak obatobat terlarang bagi kesehatan

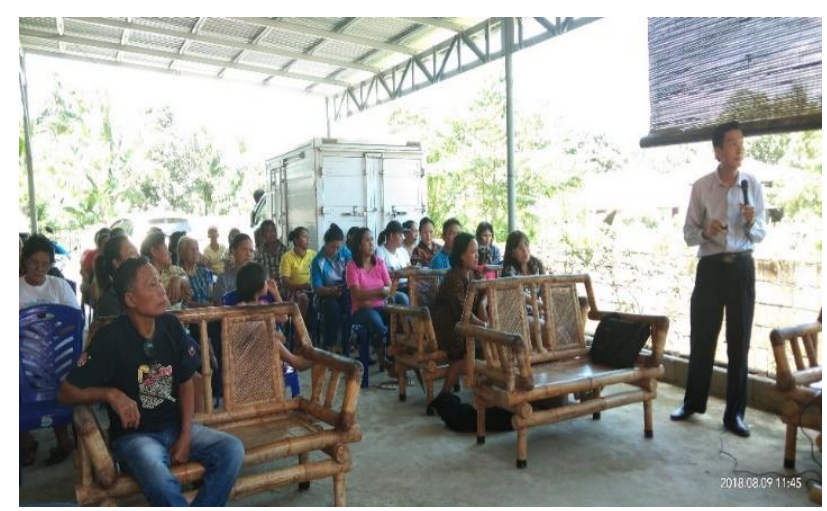

Gambar 2. Kelompok ibu-ibu Kelurahan Meras

Menurut Undang-Undang RI Nomor 35 tahun 2009, Narkotika adalah zat atau obat yang berasal dari tanaman atau bukan tanaman, baik sintetis maupun semisintetis, yang dapat menyebabkan penurunan atau perubahan kesadaran, hilangnya rasa, mengurangi sampai menghilangkan rasa nyeri, dan dapat menimbulkan ketergantungan.

Psikotopika adalah zat atau obat bukan narkotika, baik alamiah maupun sintesis, yang 
VIVABIO

Jurnal Pengabdian Multidisiplin

memiliki khasiat psikoaktif melalui pengaruh selektif pada susunan saraf pusat yang menyebabkan perubahan khas pada 19 aktivitas normal dan perilaku. (Dirjosisworo, 1986 disitasi oleh Amanda, 2017).

Zat adiktif lainnya adalah zat-zat selain narkotika dan psikotropika yang dapat menimbulkan ketergantungan pada pemakainya, diantaranya adalah rokok, kelompok alkohol dan minuman lain yang memabukkan dan menimbulkan ketagihan, thiner dan zat lainnya, seperti lem kayu, penghapus cair dan aseton, cat, bensin yang bila dihirup akan dapat memabukkan (Alifia, 2008 disitasi oleh Amanda, 2017)

Penyalahgunaan obat-obat terlarang dapat terlihat pada fisik maupun psikis seseorang, dampak bagi kesehatan dan penyakit-penyakit yang ditimbulkan serta gejala-gejala psikis yang muncul yaitu:

1. Gangguan pada sistem saraf seperti: kejang-kejang, halusinasi, gangguan kesadaran, kerusakan syaraf tepi

2. Gangguan pada jantung dan pembuluh darah seperti: infeksi akut otot jantung, gangguan peredaran darah

3. Gangguan pada kulit seperti: penanahan (abses), alergi, eksim

4. Gangguan pada paru-paru seperti: penekanan fungsi pernapasan, kesukaran bernafas, pengerasan jaringan paru-paru

5. Sering sakit kepala, mual-mual dan muntah, suhu tubuh meningkat, pengecilan hati dan sulit tidur

6. Pada kesehatan reproduksi adalah gangguan pada endokrin, seperti: penurunan fungsi hormon reproduksi (estrogen, progesteron, testosteron), serta gangguan fungsi seksual

7. Kesehatan reproduksi pada remaja perempuan antara lain perubahan periode menstruasi, ketidakteraturan menstruasi, dan amenorhoe (tidak haid)

8. Bagi pengguna narkoba melalui jarum suntik, khususnya pemakaian jarum suntik secara bergantian, risikonya adalah tertular penyakit seperti hepatitis B, C, dan HIV.

Dalam kegiatan ini juga dijelaskan bagaimana peran orangtua dalam pencegahan penyalahgunaan narkotika dan obat-obat terlarang terhadap anak-anak usia sekolah di lingkungan keluarga masing-masing, yaitu dengan cara orangtua memberikan contoh dalam kehidupan sehari-hari secara baik dan benar, membantu anak dalam mengatasi masalah yang dihadapi dengan bijaksana dan membiasakan anak untuk berterus terang dalam mengemukakan masalahnya. Orangtua juga dapat mengarahkan anak dalam menggali dan mengembangkan potensi diri dalam bidang seni, olahraga, jurnalistik dan kegiatan-kegiatan organisasi sekolah seperti pramuka, palang merah remaja, dan cinta alam. Pentingnya juga orangtua memberikan pemahaman kepada anak tentang bahaya narkotika dan obat-obat terlarang dapat mengakibatkan berhenti sekolah, tidak dapat bekerja dengan baik, terlibat tindak pidana, mengganggu ketertiban umum dan terkena berbagai macam penyakit.

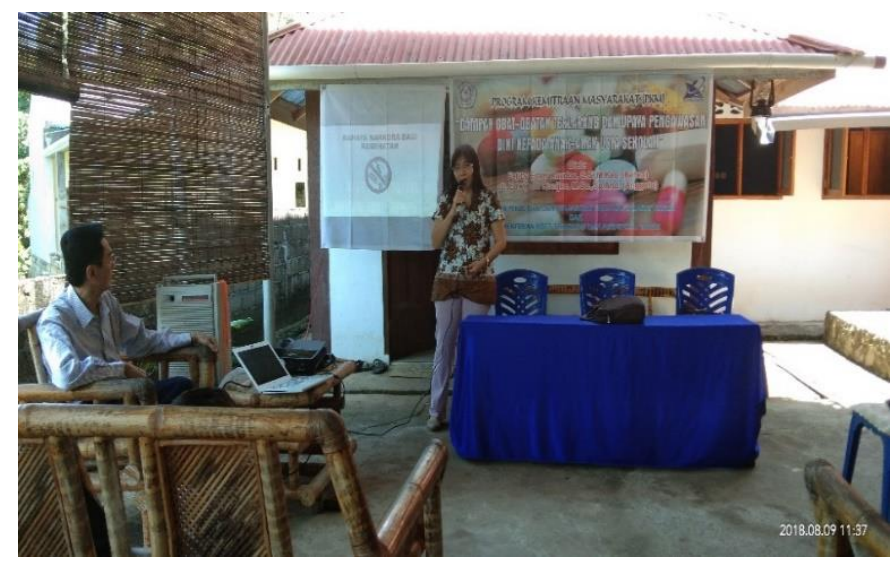

Gambar 3. Kegiatan sosialisasi peranan orangtua dalam pencegahan narkoba

Kelompok Ibu-ibu Kelurahan Meras Kecamatan Bunaken sebagai mitra sangat antusias mendengarkan penjelasan dari tim penyuluh program kemitraan masyarakat (PKM) yang bekerjasama dengan Lembaga Penelitian dan Pengabdian kepada Masyarakat (LPPM) Unsrat Manado. Kelompok Ibu-ibu ini diarahkan 
VIVABIO

Jurnal Pengabdian Multidisiplin

untuk menjadi motivator dalam memerangi narkotika dan obat-obat terlarang dalam lingkungan keluarga masing-masing maupun lingkungan masyarakat melalui kegiatan simulasi kampanye bahaya narkoba. Dalam lingkungan keluarga, orangtua khususnya sosok ibu sangat berperan dalam pembentukan karakter anak-anak mulai dari kecil karena memiliki waktu yang cukup untuk mendidik dan mengawasi anakanaknya. Pemahaman tentang faktor-faktor penyebab penyalahgunaan narkoba dan upaya pencegahannya sangat penting dibekali kepada orangtua yaitu:

Faktor-faktor penyebab penyalahgunaan narkoba:

1. Faktor pendorong; pengendalian diri lemah, keluarga, gangguan perilaku, pemberontak, tidak berprestasi di sekolah, tidak diterima di kelompok, berteman dengan pemakai

2. Faktor individu: periode remaja (ingin tahu, coba-coba, ingin diakui oleh teman)

3. Faktor lingkungan; keluarga dan pergaulan

Pencegahan narkoba serta usaha-usaha yang dapat dilakukan dalam lingkungan keluarga dan masyarakat.

Upaya pencegahan penyalahgunaan narkoba:

1. Peran remaja : ikut kegiatan ekstra yaitu olahraga, kesenian, ketrampilan, beribadah, dan tidak bergaul dengan pecandu

2. Peran orangtua: menciptakan rumah yang harmonis, kemudahan berkomunikasi, mendidik yang baik, memberi contoh yang baik, dan mengawasi anak-anak

3. Sosialisasi Program P4GN (pencegahan dan pemberantasan terhadap penyalahgunaan narkoba)

Menurut BNN dalam Buku Panduan Pencegahan Penyalahgunaan Narkoba Sejak Dini (2012), peran orangtua dalam pencegahan penyalahgunaan narkotika adalah sebagai berikut:

1. Orangtua sebagai panutan dalam kehidupan sehari-hari. Berlaku jujur dan mau mengakui kelemahan dan kekurangan tanpa harus kehilangan wibawa.
2. Orangtua sebagai pembimbing dan pendidik dalam membantu anak mengatasi masalah yang dihadapi.

3. Orangtua memberikan alternatif penyelesaian masalah dengan bijaksana. Perlakukan anak seperti layaknya teman sendiri.

4. Orangtua memberikan arahan kepada anak dalam menggali potensi diri dengan mengembangkan keahlian atau keterampilan khusus

5. Orangtua memberi pemahaman bahwa penyalahgunaan narkotika dan prekursor narkotika dapat mengakibatkan putus sekolah, tidak dapat bekerja dengan baik, terlibat tindak pidana, mengganggu ketertiban umum dan terkena berbagai macam penyakit.

6. Menyadarkan anak bahwa penyalahgunaan narkotika dan prekursor narkotika tidak sesuai dengan nilai, norma yang berlaku dalam agama dan masyarakat.

7. Orangtua tempat bertanya dan teman diskusi. Menjadikan diri anda sebagai teman yang pertama memberikan informasi dan bekali diri anda dengan pengetahuan tentang narkotika dan prekursor narkotika dari media yang ada.

8. Jadilah pendengar yang baik. Jangan bereaksi berlebihan apabila anak mengungkapkan pendapatnya tentang masalah narkotika dan prekusor narkotika.

9. Melibatkan diri dalam kegiatan anak. Menciptakan situasi agar anak dapat dekat dengan anda. Bina kebersamaan dengan menciptakan kegiatan rutin bersama anak. Kerjakan kegiatan di rumah bersama seluruh keluarga di hari libur. Ciptakan kesempatan untuk rekreasi bersama.

10. Membuat aturan keluarga yang jelas dan tegas. Aturan dibuat atas kesepakatan anggota keluarga. Jelaskan konsekuensinya, apabila aturan dilanggar. Mengontrol kegiatan anak.

11. Mengembangkan tradisi keluarga dalam nilai-nilai agama. Menunaikan ibadah atau 
VIVABIO

Jurnal Pengabdian Multidisiplin

berdoa bersama. Budayakan untuk mengakui kesalahan baik anak kepada orangtua atau sebaliknya. Libatkan anak-anak dalam mewujudkan harapan/cita-cita keluarga. Berikan semangat kepada anak dalam meraih cita-cita/ harapannya.

12. Menanamkan disiplin pada anak

Tips menghindarkan diri dari narkoba

1. Tingkatkan iman dan taqwa,

2. Siapkan diri dan mental untuk menolak apabila ditawari narkoba

3. Hati-hati dalam memilih teman bergaul.

4. Belajar berkata "Tidak" apabila ditawari dengan alasan yang tepat, kalau tidak mampu segera tinggalkan tempat itu

5. Tingkatkan prestasi untuk mengejar citacita dan keinginan yang lebih mulia.

6. Untuk mengisi waktu luang lakukan kegiatan yang positif.

\section{KESIMPULAN DAN SARAN}

\section{Kesimpulan}

1. Dampak dari penyalahgunaan narkotika dan obat-obat terlarang sangat berbahaya bagi kesehatan tubuh manusia

2. Pengawasan dini kepada anak-anak usia usia sekolah terhadap bahaya narkoba harus lebih ditingkatkan

\section{Saran}

Perbanyak kegiatan pelatihan bagi motivator dalam mengampanyekan antinarkoba khususnya bagi anak-anak usia sekolah

\section{UCAPAN TERIMAKSIH}

Terimakasih kepada Lembaga Penelitian dan Pengabdian kepada Masyarakat Universitas Sam Ratulangi (LPPM-Unsrat) yang telah membiayai kegiatan pengabdian ini pada tahun 2018.

Terimakasih juga kepada masyarakat Kelurahan Meras Kecamatan Bunaken Manado yang telah menerima tim pengabdian untuk melakukan kegiatan penyuluhan.

\section{REFERENSI}

Amanda, MP, S. Humaedi, MB. Santoso. 2017. Penyalahgunaan Narkoba di Kalangan Remaja (Adolescent Substance Abuse). Jurnal Penelitian dan PPM Vol. 4(2): 339345

BNN. 2012. Buku Panduan Pencegahan Penyalahgunaan Narkoba Sejak Dini. Direktorat Diseminasi Informasi, Deputi Bidang Pencegahan. Jakarta

Barometer SULUT Online. 2017. BNNK Manado dan BNNP Sulut Sambangi Wilayah Rawan Narkoba. http://www.barometersulut.com/index.php /2017/05/22/bnnk-manado-dan-bnnpsulut-sambangi-kelurahan-wonasa/

Koran Sindo Online. 2017. 40\% Pengguna Narkoba Pelajar \& Mahasiswa. https://nasional.sindonews.com/read/1257 498/15/40-pengguna-narkoba-pelajarmahasiswa-1510710950

Makawekes, N., Lyndon R.J. Pangemanan, Melsje Y. Memah. 2016. Dinamika Kelompok Tani Cempaka di Kelurahan Meras Kecamatan Bunaken Kota Manado. Cocos Vol. 7 (3)

Nismarianna. 2017. Bahaya Narkoba bagi Remaja dan Pelajar.

http://indokku.com/2017/06/13/artikel-bahayanarkoba-bagi-remaja-dan-pelajar/

Okezone. 2018. 5,9 Juta Anak Indonesia Jadi Pecandu Narkoba. https://news.okezone.com/read/2018/03/ 06/337/1868702/5-9-juta-anak-

indonesia-jadi-pecandu-narkoba

Okezone. 2018. Polisi Ungkap Tiga Kasus Peredaran Narkoba di Manado dalam Sepekan.

https://news.okezone.com/read/2018/01/2 5/340/1850399/polisi-ungkap-tiga-kasusperedaran-narkoba-di-manado-dalamsepekan

Republika Online. 2017. BNN: 27 Persen Pengguna Narkoba Pelajar dan Mahasiswa. https://www.republika.co.id/berita/nasiona 
VIVABIO

Jurnal Pengabdian Multidisiplin

1/daerah/17/10/30/oymn2n423-bnn-27persen-pengguna-narkoba-pelajar-danmahasiswa

https://mochamadrizal19.wordpress.co m/akibat-penggunaan-
ISSN

narkoba/Akibat Penggunaan Narkoba

Undang-undang Republik Indonesia No. 35 Tahun 2009 tentang Narkoba 